\title{
A DÍVIDA PÚBLICA E A AUTONOMIA DOS ENTES FEDERADOS
}

\section{José Augusto Moreira de Carvalho}

Doutor e Mestre em Direito Econômico e Financeiro pela Faculdade de Direito da Universidade de São Paulo. Advogado em São Paulo.

\section{SUMÁRIO}

Considerações iniciais - 1. Disciplina constitucional e legal do endividamento subnacional -2 . As vedações impostas aos entes subnacionais para a realização de operações de crédito: violação à autonomia dos entes federados e ao princípio da separação de poderes?: 2.1 As resoluções do Senado e a questão da autonomia dos entes subnacionais; $2.2 \mathrm{O}$ trâmite de autorização do Senado para a realização de determinadas operações de crédito e novamente a questão da autonomia dos entes subnacionais; $2.3 \mathrm{O}$ papel do Ministério da Fazenda nas operações de crédito dos entes subnacionais e a questão da separação dos Poderes e da autonomia dos entes federados - Conclusão - Referências. 


\section{CONSIDERAÇÕES INICIAIS}

Ponto relevante no estudo do federalismo brasileiro é a percepção acerca do grau de autonomia dos entes que fazem parte do Estado Federado.

$\mathrm{Na}$ dinâmica dessa análise, não se pode deixar de observar, em primeiro lugar, qual o nível de concentração de poder no governo central.

No caso do Brasil, a prevalência do papel do governo central no federalismo pode ser explicada, em parte, pela própria formação da Federação, que se originou por intermédio de segregação, na qual as províncias transmudaram-se em Estados pela força de um decreto.

Esse detalhe, de início, já expõe justificativas importantes que explicitam, no caso brasileiro, a grande concentração de poder no governo central.

Forçoso reconhecer que nas federações constituídas por intermédio da agregação, nas quais os Estados abrem mão de suas respectivas soberanias para a constituição de uma Federação, a tendência de uma maior autonomia dos entes subnacionais é preponderante. De fato, apesar de abdicarem de suas soberanias, esses Estados concordaram em se unir com vistas a um bem maior (pacto federativo), mas com a preocupação de estabelecerem mecanismos verticais e horizontais seguros para permitir o exercício satisfatório de suas respectivas autonomias.

$\mathrm{Na}$ Federação brasileira, essa lógica não ocorreu, pois se partiu de uma matriz unitária - já com alto poder em mãos do governo central - para um modelo descentralizado, obtido por intermédio da concessão de uma relativa autonomia aos entes subnacionais (províncias que, em razão disso, passaram à categoria de Estados), tudo de forma automática, mediante um decreto ${ }^{1}$, como mencionado.

1 O Decreto n. 1, de 15 de novembro de 1889, que proclamou provisoriamente e decretou como forma de governo a República Federativa, expôs em seus artigos a transformação automática das províncias em Estados, concedendo-lhes autonomia, embora no texto conste o termo "soberania”. Eis os principais artigos do decreto: “Art. $1^{\circ}$ Fica proclamada provisoriamente e decretada como a forma de governo da Nação brasileira - a República Federativa. Art. $2^{\circ}$ As Províncias do Brasil, reunidas pelo laço da Federação, ficam constituindo os Estados Unidos do Brasil. Art. $3^{\circ}$ Cada um desses Estados, no exercício de sua legítima soberania, decretará oportunamente a sua constituição definitiva, elegendo os seus corpos deliberantes e os seus Governos locais. (...) Art. $9^{\circ}$ Ficam igualmente subordinadas ao Governo Provisório da República todas as repartições civis e militares até aqui subordinadas ao Governo central da Nação brasileira." Da mesma forma, a Constituição de 1891, em seu artigo $1^{\circ}$, estabelece de forma nítida a transformação das antigas províncias em Estados da nova Federação: "Art $1^{\circ}$ A Nação brasileira adota como forma de Governo, sob o regime representativo, a República Federativa, proclamada a 15 de novembro de 1889, e constitui-se, por união perpétua e indissolúvel das suas antigas Províncias, em Estados Unidos do Brasil”. 
Necessário considerar que, nessas condições, o exercício de uma autonomia razoável pelos entes subnacionais já não se torna tão evidente, destacando-se o poder do governo central sobre os demais entes federados. Aliás, essa tônica prevalece nas Constituições que se seguiram à Proclamação da República, conforme esclareceu o Ministro Paulo Brossard em voto na Medida Cautelar em Ação Direta de Inconstitucionalidade n. 216 (Paraíba) ${ }^{2}$ :

No Brasil, a verdade é que o período de 30 a 34 foi um período unitário; o período que vem de 37 a 46 é um período unitário; o período que começa em 65 e vai a 67 foi um período fortemente unitário; no período que se inicia em 69 e durou não sei quantos anos, malfadados anos, também a federação foi reduzida a uma ficção.

A observação que se tem feito notar é que embora se clame muito por federação pouco se pratica a federação, quando se tem efetivamente a competência para usá-la.

No mesmo julgado, o Ministro Celso de $\mathrm{Mello}^{3}$ esclareceu a existência de relevante restrição à autonomia dos entes subnacionais no âmbito da Constituição de 1988. Eis o excerto do seu voto:

O perfil da federação brasileira, redefinido pela Constituição de 1988, embora aclamado por atribuir maior autonomia, especialmente no domínio tributário, aos Estados-membros (MICHEL TEMER, 'Elementos de direito constitucional', $5^{\text {a }}$ ed., p. 72, 1988, Revista dos Tribunais; PINTO FER-

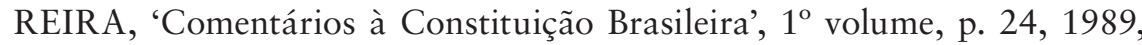
Saraiva; JOSÉ AFONSO DA SILVA, 'Curso de Direito Constitucional Positivo', $5^{\text {a }}$ ed., p. 514, 1988, Revista dos Tribunais, inter plures), é visto com reserva por alguns autores, que consideram persistir no Brasil um federalismo ainda afetado por excessiva centralização espacial do poder em torno da União Federal.

CELSO BASTOS, ao discorrer sobre 'A federação nas Constituições brasileiras’ (Revista Procuradoria-Geral do Estado de São Paulo, n. 29, p. 61, jun/88), feriu, precisamente, esse aspecto da questão, verbis:

'(...)

É lamentável que o constituinte não tenha aproveitado a oportunidade para atender ao que era o grande clamor nacional no sentido de uma revitalização do nosso princípio federativo. O Estado brasileiro na nova Constituição

2 Relator Min. Célio Borja, julgado em 23.05.90, por maioria (Tribunal Pleno), publicado no D.J. de 07.05.93.

3 Relator Min. Célio Borja, julgado em 23.05.90, por maioria (Tribunal Pleno), publicado no D.J. de 07.05.93. 
ganha níveis de centralização superiores à maioria dos Estados que se consideram unitários e que pela via de uma centralização por regiões ou por províncias, consegue um nível de transferência das competências tanto legislativas quanto de execução muito superior àquele alcançado pelo Estado brasileiro. Continuamos pois sob uma Constituição eminentemente centralizadora e se alguma diferença existe relativamente à anterior é no sentido de que este mal (para aqueles que entendem ser uma mal) agravou-se sensivelmente.'

Tendo presente essa divergência doutrinária - que reputo de sumo relevo político-jurídico, pois, a partir de sua resolução por esta Corte, definir-se-á, como tema essencial à organização político-administrativa do Estado brasileiro, o modelo de Federação a ser efetivamente observado nas práticas institucionais - não vejo, ao menos neste momento procedimental, como aderir à tese tão doutamente exposta pelo eminente Relator. Se é certo que a nova Carta Política contempla um elenco menos abrangente de princípios sensíveis, a denotar, com isso, a expansão de poderes jurídicos na esfera das coletividades locais, o mesmo não se pode afirmar quanto aos princípios extensiveis e aos princípios constitucionais estabelecidos, os quais, embora disseminados pelo texto constitucional, posto que não é tópica a sua localização, configuram acervo expressivo de limitações dessa autonomia local, cuja identificação - até mesmo pelos próprios efeitos restritivos que deles decorrem - impõe-se realizar. (destaques inseridos).

Até mesmo nas federações modernas, como a dos Estados Unidos da América, inicia-se uma tendência a uma maior concentração de poder no governo central, com interferência em questões afetas aos entes subnacionais. De fato, embora a Federação americana tenha iniciado com uma expressiva descentralização, aos poucos esse movimento foi arrefecendo, continuando nesse viés até os dias atuais. Antonio Celso Banheta Mioto ${ }^{4}$ expõe os últimos movimentos de centralização ocorridos na Federação americana:

Após a Segunda Guerra Mundial, essa centralização não mudou substancialmente de figura, apenas transmutando-se num Estado de caráter intervencionista de perfil mais elaborado, o chamado Welfare State, ou estado do bem-estar social, do Estado provedor por excelência, cujo embrião, como exposto, estava lá no início do século XX, mas de modo mais evidente a partir dos anos 1930 como resposta à grande depressão dos anos 1920

4 Para onde vai o federalismo? Notas sobre o que foi e o que poderá vir a ser o Estado Federal. Revista de Direito Administrativo, Rio de Janeiro, v. 268, p. 195-196, jan. 2015. ISSN 2238-5177. Disponível em: <http://bibliotecadigital.fgv.br/ojs/index.php/rda/article/view/50739>. Acesso em: 20 Jul. 2018. 
nos EUA, notadamente em seu ápice no ano de 1929 com a quebra da Bolsa de Valores de Nova York.

O New Deal, gestado e posto em marcha num Estado ainda bastante centralizado e interventivo, funcionava, e efetivamente foi assim que ocorreu, como uma espécie de 'contrato social' entre o Estado e o povo. Trouxe consigo um rompimento com o modelo de Estado baseado no federalismo dual, com competências federais e estaduais rigidamente demarcadas, e lançou as bases, como vimos, não só do Welfare State, mas mesmo de uma visão que poderíamos nominar como ‘justo assistencialismo' (Fair Deal), posta em marcha tempos depois, dos anos 1960 em diante, especialmente com a promulgação do Civil Rights Act, de 1964.

O fato é que os conflitos surgidos até a primeira metade do século XX de certa forma justificaram a perda da descentralização estatal, antes incensada como qualidade fundamental do federalismo (o que é de fato verdadeiro). Para defender a nação, preservar seus valores e principalmente manter a unidade, mostrava-se aceitável abrir mão da independência dos entes componentes do Estado Federal, estados e municípios, em prol de uma força única mais coesa.

Em tempos atuais, muito embora com algumas mudanças neste quadro, o fato é que vivemos resquícios fortes dessa época. Obviamente, o tom grandiloquente de recuperação e disciplina, típicos do New Deal, mudou, mas o fato é que o Congresso Nacional americano continua tutelando bastante e, baseado na interpretação dos interesses estaduais, pode legislar e regular praticamente tudo, da matéria mais genérica possível até o interesse substancialmente local.

Apesar dessa tendência à concentração de poder no governo central, as reais implicações de um maior ou menor grau de centralização não podem ser analisadas sem que se estude, individualmente, as perspectivas da descentralização (política, fiscal, constitucional, estrutural e de políticas) para, a partir daí, se ter a devida noção de como cada uma delas afeta o funcionamento da Federação.

No presente estudo, contudo, não se adentrará em cada uma dessas perspectivas, pois o objetivo não é realizar um juízo amplo a respeito do nível de descentralização da Federação brasileira, mas sim examinar a relação existente entre a dívida pública e a autonomia dos entes federados, aspecto esse que implicará a apreciação da perspectiva da descentralização fiscal.

É nessa perspectiva que se depreende que os entes federados brasileiros, para bem exercerem seus papéis, valem-se: a) das parcelas dos tributos por eles arrecadados ou a eles transferidos por outros entes ou fundos; b) das transferências voluntárias de outros entes (da União para Estados, Distrito Federal ou Municípios; ou dos Estados para os Municípios); c) de endividamentos. 
Relevante considerar que, sob a ótica da descentralização fiscal, são levados em consideração diversos fatores, dentre os quais: a) a forma como estão dispostas as receitas e as despesas no âmbito dos entes subnacionais, bem como o efetivo grau de autoridade do respectivo ente para efetuar esses gastos em contraposição à interferência do governo central; b) as origens do financiamento do gasto público (receitas próprias, transferências, empréstimos) e a forma pela qual ocorre ingerência do poder central na autonomia do ente subnacional para obtenção desse financiamento; c) eventuais limitações ditadas pelo governo central para que os entes subnacionais se endividem 5 .

No campo da dívida pública, o que interessará exatamente à presente análise será o nível de autoridade dos entes subnacionais brasileiros (Estados e Municípios) para efetuarem seus respectivos endividamentos, levando em consideração eventuais influências do governo central nesse processo.

Para essa compreensão, necessário avaliar, primeiramente, como se arquiteta no ordenamento jurídico brasileiro esse poder (ou não) de os entes subnacionais se endividarem.

\section{DISCIPLINA CONSTITUCIONAL E LEGAL DO ENDIVIDAMENTO SUBNACIONAL}

$\mathrm{Na}$ Constituição Federal brasileira consta expressa autorização à União para ditar normas gerais sobre Direito Financeiro e orçamento ${ }^{6}$.

É nesse sentido que a Lei 4.320, de 17 de março de 1964, embora anterior à Constituição Federal de 1988, foi por ela recepcionada como lei complementar, portanto, norma geral de Direito Financeiro destinada a disciplinar a elaboração e controle dos orçamentos e balanços da União, dos Estados, dos Municípios e do Distrito Federal.

A Lei de Responsabilidade Fiscal (Lei Complementar n. 101, de 4 de maio de 2000) também é uma norma geral e estabelece diretrizes para a responsabilidade na gestão fiscal.

5 Jonathan Rodden. Federalismo e descentralização em perspectiva comparada: sobre significados e medidas. Tradução de Miriam Adelman e Marta Arretche. Revista de Sociologia e Política, Curitiba, n. 24, p. 10-15, Jun. 2005. Disponível em: http://www.scielo.br/scielo.php?pid=S0104$-44782005000100003 \&$ script=sci_arttext\&tIng=, acessado em 01.08.2018.

6 De fato, assim prevê o artigo 24 da Constituição Federal: “Art. 24. Compete à União, aos Estados e ao Distrito Federal legislar concorrentemente sobre: I - direito tributário, financeiro, penitenciário, econômico e urbanístico; II - orçamento; (...) $\mathbb{1} 1^{\circ}$ No âmbito da legislação concorrente, a competência da União limitar-se-á a estabelecer normas gerais”. 
Em ambas as normas (Lei 4.320/64 e LRF) há disposições sobre a dívida pública dos entes federados.

Há, ainda, a Lei de Diretrizes Orçamentárias (LDO) - norma que, em cada esfera da Federação, dá embasamento à elaboração da Lei Orçamentária Anual (LOA) -, na qual também se estabelecem algumas orientações a respeito de dívida pública? .

No que se refere aos parâmetros e limites de endividamento dos entes subnacionais, algumas disposições descritas no artigo 52 da Constituição Federal ganham relevância. São elas:

Art. 52. Compete privativamente ao Senado Federal:

(...)

V - autorizar operações externas de natureza financeira, de interesse da União, dos Estados, do Distrito Federal, dos Territórios e dos Municípios; VI - fixar, por proposta do Presidente da República, limites globais para o montante da dívida consolidada da União, dos Estados, do Distrito Federal e dos Municípios;

VII - dispor sobre limites globais e condições para as operações de crédito externo e interno da União, dos Estados, do Distrito Federal e dos Municípios, de suas autarquias e demais entidades controladas pelo Poder Público federal;

VIII - dispor sobre limites e condições para a concessão de garantia da União em operações de crédito externo e interno;

IX - estabelecer limites globais e condições para o montante da dívida mobiliária dos Estados, do Distrito Federal e dos Municípios; (...)

Depreende-se, assim, que cabe ao Senado estabelecer os parâmetros para o endividamento dos entes subnacionais. Foi justamente com base nesses permissivos constitucionais que editou duas resoluções sobre a questão: a de n. 40, de 20 de dezembro de 2001, e a de n. 43, de 25 de dezembro de 2001.

A Resolução 40/2001 dispõe sobre os limites globais para o montante da dívida pública consolidada e da dívida pública mobiliária dos Estados, do Distrito Federal e dos Municípios, em obediência ao disposto nos incisos VI e IX, do artigo 52, da Constituição Federal.

Veja-se, a propósito, o que disciplina o artigo $4^{\circ}$, parágrafo $1^{\circ}$, da LRF: “Art. $4^{\circ}$ A lei de diretrizes orçamentárias atenderá o disposto no $\mathbb{2} 2^{\circ}$ do art. 165 da Constituição e: (...) $\mathbb{S} 1^{\circ}$ Integrará o projeto de lei de diretrizes orçamentárias Anexo de Metas Fiscais, em que serão estabelecidas metas anuais, em valores correntes e constantes, relativas a receitas, despesas, resultados nominal e primário e montante da dívida pública, para o exercício a que se referirem e para os dois seguintes”. 
Entende-se por dívida pública consolidada ou fundada o valor total das obrigações financeiras adquiridas pelo ente subnacional em decorrência de operações de crédito: a) mediante emissão de títulos públicos (dívida mobiliária); b) em razão de lei, contrato, convênio ou tratado, para amortização em prazo que exceda o exercício financeiro (superior a doze meses); c) de prazo inferior a doze meses, que tenham constado como receitas no orçamento. Além disso, estão incluídos na dívida consolidada os precatórios judiciais emitidos a partir de 5 de maio de 2000 e que não foram honrados durante a execução do orçamento nos quais foram incluídos. A dívida consolidada líquida representa todas essas obrigações, subtraídas as disponibilidades de caixa, as aplicações financeiras e os demais haveres financeiros.

A dívida consolidada líquida dos Estados e do Distrito Federal não pode exceder a duas vezes $(200 \%)$ as suas respectivas receitas correntes líquidas; no caso dos Municípios, tal limite é de 1,2 vezes (120\%). A extrapolação desses limites provoca algumas restrições aos entes, dentre elas a possibilidade de contratar novas operações de crédito $^{8}$.

A receita corrente líquida representa todo o montante das receitas tributárias, de contribuições, patrimoniais, industriais, agropecuárias, de serviços, transferências correntes e outras receitas correntes, deduzidos: a) nos Estados, a parcela entregue aos Municípios por determinação constitucional; b) nos Estados e Municípios, a contribuição dos servidores para o custeio de seu sistema de previdência e assistência social e as receitas provenientes da compensação financeira prevista no artigo $201, \mathbb{S} 9^{\circ}$, da Constituição Federal ${ }^{9}$.

8 É no artigo 31 da LRF que se encontram disciplinadas as mencionadas restrições: “Art. 31. Se a dívida consolidada de um ente da Federação ultrapassar o respectivo limite ao final de um quadrimestre, deverá ser a ele reconduzida até o término dos três subsequentes, reduzindo o excedente em pelo menos $25 \%$ (vinte e cinco por cento) no primeiro. $\$ 1^{\circ}$ Enquanto perdurar o excesso, o ente que nele houver incorrido: I - estará proibido de realizar operação de crédito interna ou externa, inclusive por antecipação de receita, ressalvado o refinanciamento do principal atualizado da dívida mobiliária; II - obterá resultado primário necessário à recondução da dívida ao limite, promovendo, entre outras medidas, limitação de empenho, na forma do art. $9^{\circ}$. $\mathbb{S}$ $2^{\circ}$ Vencido o prazo para retorno da dívida ao limite, e enquanto perdurar o excesso, o ente ficará também impedido de receber transferências voluntárias da União ou do Estado. $\mathbb{S} 3^{\circ}$ As restrições do $\mathbb{S} 1^{\circ}$ aplicam-se imediatamente se o montante da dívida exceder o limite no primeiro quadrimestre do último ano do mandato do Chefe do Poder Executivo. $\ 4^{\circ} \mathrm{O}$ Ministério da Fazenda divulgará, mensalmente, a relação dos entes que tenham ultrapassado os limites das dívidas consolidada e mobiliária. $\mathbb{S} 5^{\circ}$ As normas deste artigo serão observadas nos casos de descumprimento dos limites da dívida mobiliária e das operações de crédito internas e externas".

9 Assim prevê o citado dispositivo constitucional: "Art. 201. (...) $\mathbb{S} 9^{\circ}$ Para efeito de aposentadoria, é assegurada a contagem recíproca do tempo de contribuição na Administração Pública e 
Importante notar que a Resolução 40/2001 não estabelece limites globais para a União; apenas aos entes subnacionais.

A Resolução 43/2001 regulamenta as operações de crédito interno e externo dos Estados, do Distrito Federal e dos Municípios, inclusive no tocante à concessão de garantias, seus limites e condições de autorização.

$\mathrm{O}$ artigo $3^{\circ}$ da mencionada resolução enumera várias situações que caracterizam uma operação de crédito e que são a ela equiparáveis. Nesse sentido, são operações de crédito os compromissos assumidos com credores internos ou externos, provenientes de: mútuo, abertura de crédito, emissão e aceite de título, aquisição financiada de bens, recebimento antecipado de valores provenientes da venda a termo de bens e serviços, arrendamento mercantil, outras operações similares, inclusive com a utilização de derivativos financeiros.

Também são equiparadas a operações de crédito: o recebimento antecipado de valores de empresa na qual o ente subnacional detenha, ainda que indiretamente, a maioria do capital social votante, excetuando-se dessa regra os lucros e dividendos; a assunção de compromisso, a confissão de dívida ou outra operação assemelhada, estabelecida com fornecedor de bens, mercadorias ou serviços, por intermédio de emissão, aceite ou aval de títulos de crédito; a assunção de obrigação com fornecedores, sem aprovação orçamentária, para pagamento de bens e serviços em momento posterior.

A Lei de Responsabilidade Fiscal, em seu artigo 29, inciso III, reitera o conceito de operação de crédito e, no parágrafo $1^{\circ}$, dá uma abrangência maior às situações de equiparação ao estendê-las, genericamente, às hipóteses de assunção, reconhecimento ou confissão de dívidas pelo ente da Federação, sem fazer qualquer restrição, o que remete a uma interpretação ampliativa do conceito.

$\mathrm{O}$ artigo $6^{\circ}$ da Resolução 43/2001 foi redigido com a finalidade de estabelecer parâmetros e diretrizes para o cumprimento do artigo 167 da Constituição Federal, que veda a "realização de operações de créditos que excedam o montante das despesas de capital, ressalvadas as autorizadas mediante créditos suplementares ou especiais ${ }^{10}$ com finalidade precisa" e devidamente aprovadas pelo Poder Legislativo.

na atividade privada, rural e urbana, hipótese em que os diversos regimes de previdência social se compensarão financeiramente, segundo critérios estabelecidos em lei”.

10 "Compreendem-se como créditos especiais aqueles dirigidos a despesas para as quais não existe dotação orçamentária específica (art. 41, II, da Lei 4.320/1964). (...) Os créditos suplementares são aqueles destinados à ampliação da dotação orçamentária, conforme art. 41, I, da lei 4.320/1964; ao contrário dos créditos especiais e extraordinários, não podem vigorar além do exercício financeiro em que são autorizados, ainda que essa permissão ocorra nos últimos 
As despesas de capital são aquelas que revertem em ativos ao ente que as concretizam, ou seja, resultarão, no futuro, em um bem de capital em prol do ente federado que realizou a despesa. É por essa razão que as despesas de capital originam-se de investimentos, inversões financeiras e transferências de capital ${ }^{11}$. Contrapõem-se, assim, às despesas correntes, que são aquelas destinadas à manutenção do Estado e que se originam de despesas de custeio e de transferências correntes ${ }^{12}$.

Já no artigo $7^{\circ}$ da Resolução 43/2001 se encontram os limites de endividamento dos entes subnacionais para as operações de crédito interno e externo, assim descritos: a) o total das operações de crédito realizadas em um exercício financeiro não poderá superar $16 \%$ da receita corrente líquida; b) não poderá

quatro meses do referido exercício” (José Augusto Moreira de Carvalho. Do exercício financeiro. In: CONTI, José Mauricio. Orçamentos públicos: A Lei 4.320/1964 comentada. São Paulo: Revista dos Tribunais, p. 140-141).

11 A Lei 4320, de 17 de março de 1964, em seu artigo 12, dá o conceito de investimentos, inversões financeiras e transferências de capital: "Art. 12. (...) $\mathbb{S} 4^{\circ}$ Classificam-se como investimentos as dotações para o planejamento e a execução de obras, inclusive as destinadas à aquisição de imóveis considerados necessários à realização destas últimas, bem como para os programas especiais de trabalho, aquisição de instalações, equipamentos e material permanente e constituição ou aumento do capital de empresas que não sejam de caráter comercial ou financeiro. $\mathbb{S} 5^{\circ}$ Classificam-se como Inversões Financeiras as dotações destinadas a: I - aquisição de imóveis, ou de bens de capital já em utilização; II - aquisição de títulos representativos do capital de empresas ou entidades de qualquer espécie, já constituídas, quando a operação não importe aumento do capital; III - constituição ou aumento do capital de entidades ou empresas que visem a objetivos comerciais ou financeiros, inclusive operações bancárias ou de seguros. $\$ 6^{\circ}$ São Transferências de Capital as dotações para investimentos ou inversões financeiras que outras pessoas de direito público ou privado devam realizar, independentemente de contraprestação direta em bens ou serviços, constituindo essas transferências auxílios ou contribuições, segundo derivem diretamente da Lei de Orçamento ou de lei especialmente anterior, bem como as dotações para amortização da dívida pública".

12 O mesmo artigo 12 da Lei 4.320/64 estabelece o conceito de despesas de custeio e de transferências correntes: "Art. 12. (...) $\mathbb{S} 1^{\circ}$ Classificam-se como Despesas de Custeio as dotações para manutenção de serviços anteriormente criados, inclusive as destinadas a atender a obras de conservação e adaptação de bens imóveis. $\mathbb{S} 2^{\circ}$ Classificam-se como Transferências Correntes as dotações para despesas as quais não corresponda contraprestação direta em bens ou serviços, inclusive para contribuições e subvenções destinadas a atender à manutenção de outras entidades de direito público ou privado. $\mathbb{S} 3^{\circ}$ Consideram-se subvenções, para os efeitos desta lei, as transferências destinadas a cobrir despesas de custeio das entidades beneficiadas, distinguindo-se como: I - subvenções sociais, as que se destinem a instituições públicas ou privadas de caráter assistencial ou cultural, sem finalidade lucrativa; II - subvenções econômicas, as que se destinem a empresas públicas ou privadas de caráter industrial, comercial, agrícola ou pastoril”. 
superar $11,5 \%$ da receita corrente líquida os compromissos com amortizações, juros e demais encargos da dívida consolidada, aí incluídos os valores a desembolsar daquelas operações de crédito já contratadas e a contratar; c) o valor total da dívida consolidada também não poderá ultrapassar o teto estabelecido na Resolução 40/2001, que estabelece o limite global para o montante da dívida consolidada dos entes subnacionais ${ }^{13}$. De qualquer forma, será vedada a contratação de operação de crédito dos entes subnacionais nos 120 dias anteriores ao final do mandato dos seus respectivos Chefes do Poder Executivo ${ }^{14}$.

As operações de crédito por antecipação de receita orçamentária também possuem limites descritos na resolução, não podendo superar $7 \%$ da receita corrente líquida no exercício em que estiver sendo apurado ${ }^{15}$. Mesmo diante desses limites, tais operações devem obedecer a determinados requisitos: a) não poderão ser realizadas antes do décimo dia do início do exercício; b) devem ser liquidadas, aí incluídos os juros e encargos incidentes, até o dia dez de dezembro de cada ano; c) não devem abranger encargos diversos da taxa de juros da operação, que deverá ser obrigatoriamente prefixada ou indexada à taxa básica financeira ou a outra

13 A própria Resolução n. 43/2001, porém, expressamente relaciona operações de crédito que não estão sujeitas a tais limitações. Nesse sentido é o quanto disposto no $\mathbb{3} 3^{\circ}$ do $\operatorname{artigo} 7^{\circ}$ : “Art. $7^{\circ}$ (...) $\mathbb{S} 3^{\circ}$ São excluídas dos limites de que trata o caput as seguintes modalidades de operações de crédito: I - contratadas pelos Estados e pelos Municípios com a União, organismos multilaterais de crédito ou instituições oficiais federais de crédito ou de fomento, com a finalidade de financiar projetos de investimento para a melhoria da administração das receitas e da gestão fiscal, financeira e patrimonial, no âmbito de programa proposto pelo Poder Executivo Federal; II - contratadas no âmbito do Programa Nacional de Iluminação Pública Eficiente - Reluz, estabelecido com base na Lei n. 9.991, de 24 de julho de 2000. III - contratadas diretamente com o Banco Nacional de Desenvolvimento Econômico e Social (BNDES), ou com seus agentes financeiros credenciados, no âmbito do programa de empréstimo aos Estados e ao Distrito Federal de que trata o art. 9-N da Resolução n. 2.827, de 30 de março de 2001, do Conselho Monetário Nacional (CMN), e suas alterações. IV - destinadas ao financiamento de infraestrutura para a realização da Copa do Mundo FIFA 2014 e dos Jogos Olímpicos e Paraolímpicos de 2016, autorizadas pelo Conselho Monetário Nacional (CMN)".

14 Artigo 15, caput, da Resolução n. 43/2001. O parágrafo $1^{\circ}$ do mesmo artigo 15, contudo, prevê algumas exceções, quais sejam: a) na hipótese de refinanciamento da dívida mobiliária; b) nas operações de crédito autorizadas pelo Senado Federal ou pelo Ministério da Fazenda, em nome do Senado Federal, no âmbito da própria Resolução n. 43/2001, até 120 dias antes do final do mandato do Chefe do Poder Executivo; c) nas operações de crédito destinadas ao financiamento de infraestrutura para a realização da Copa do Mundo FIFA 2014 e dos Jogos Olímpicos e Paraolímpicos de 2016, autorizadas pelo CMN.

15 Artigo 10 da Resolução n. 43/2001. 
taxa que venha a substituí-la; d) só será admitida se não estiver pendente operação anterior da mesma natureza ${ }^{16}$. Como critério de responsabilidade fiscal, não se admite a contratação de operações por antecipação de receita orçamentária no último ano de exercício do mandato do Chefe do Poder Executivo ${ }^{17}$.

As garantias a serem prestadas pelos entes subnacionais também encontram disciplinamento na Resolução 43/2001. O saldo global dessas garantias, para cada ente, não poderá ultrapassar $22 \%$ da receita corrente líquida. Referido índice pode ser elevado para $32 \%$, desde que o garantidor preencha, de forma cumulativa, os seguintes requisitos: a) não tenha sido instado a honrar garantias anteriormente prestadas, referentes aos últimos 24 meses a contar do mês da análise; b) esteja enquadrado nos limites da dívida consolidada líquida, conforme termos da Resolução 40/2001; c) esteja ajustado aos limites de despesa com pessoal descritos na Lei de Responsabilidade Fiscal; d) esteja cumprindo o Programa de Ajuste Fiscal acordado com a União, nos termos da Lei n. 9.496, de 11 de setembro de $1997^{18}$.

Estão sujeitas à autorização específica do Senado não apenas as operações de crédito externo, mas também aquelas originadas de convênios para aquisição de bens e serviços no exterior, as de emissão de títulos da dívida pública, as de emissão de debêntures ou assunção de obrigações por entidades controladas pelos entes subnacionais que não exerçam atividade produtiva ou não possuam fonte própria de receitas ${ }^{19}$.

\section{AS VEDAÇÕES IMPOSTAS AOS ENTES SUBNACIONAIS PARA A REALIZAÇÃO DE OPERAÇÕES DE CRÉDITO: VIOLAÇÃO À AUTONOMIA DOS ENTES FEDERADOS E AO PRINCÍPIO DA SEPARAÇÃO DE PODERES?}

Ponto relevante no capítulo referente ao endividamento dos entes subnacionais diz respeito às vedações e às restrições impostas a eles para a realização de operações de crédito, bem como os reflexos dessas limitações às suas respectivas autonomias e, em alguns casos, eventual ferimento ao princípio da Separação de Poderes. Os principais detalhes desses questionamentos serão a seguir expostos.

16 Artigo 14 da Resolução n. 43/2001 e artigo 38 da Lei de Responsabilidade Fiscal.

17 Artigo 15, $\mathbb{S} 2^{\circ}$, da Resolução n. 43/2001 e artigo 38, inciso IV, alínea “b”, da Lei de Responsabilidade Fiscal.

18 Artigo $9^{\circ}$ da Resolução n. 43/2001.

19 Artigo 28 da Resolução n. 43/2001 e artigo 32, $\mathbb{S} 1^{\circ}$, inciso IV, da Lei de Responsabilidade Fiscal. 


\subsection{As resoluções do Senado e a questão da autonomia dos entes subnacionais}

Poder-se-ia perquirir, num primeiro plano, quanto à constitucionalidade da edição de uma resolução, por parte do Senado Federal, com a finalidade de estabelecer parâmetros, limites e vedações ao endividamento dos entes federados.

Uma das respostas pode ser encontrada no próprio artigo 52, da Constituição Federal, já mencionado, que claramente permite que o Senado, em relação aos entes subnacionais, autorize operações externas de natureza financeira, fixe limites globais para o montante da dívida consolidada e para o montante da dívida mobiliária, bem como disponha sobre limites globais e condições para as operações de crédito externo e interno.

A mencionada competência atribuída ao Senado é exclusiva; vale dizer, não há a possibilidade de sua alçada ser transferida ${ }^{20}$. Daí a relevância que a Constituição Federal concede à Câmara Alta - a qual representa os Estados Federados - para estabelecer tais restrições à realização de operações de crédito.

A permissão constitucional, porém, não proporcionaria uma interferência do Senado na autonomia dos entes subnacionais, ferindo, com isso, um princípio também protegido pela mesma Constituição?

Evidente que ao disciplinar os limites e condições para a realização de operações de crédito, o Senado não poderá ultrapassar a fronteira do necessário para a proteção das finanças da Federação. Em outras palavras, se é verdade que a Câmara Alta deve procurar definir critérios para o resguardo do Estado Federal, não menos verdade é que tais procedimentos devem ser aplicados de uma forma a não ultrapassar ou ferir a autonomia dos próprios entes que formam essa Federação. Fica claro, assim, que a dificuldade que enfrentará o Senado residirá em estabelecer com acuidade tais balizas no âmbito de uma resolução.

Foi justamente sobre esse ponto que os Ministros do Supremo Tribunal Federal tiveram a oportunidade de se pronunciar por ocasião do julgamento de medida cautelar na Ação Direta de Inconstitucionalidade n 1.728-8, do Distrito Federal (MC-Adin 1728).

Tratava-se, na ocasião, da discussão sobre a constitucionalidade de dispositivos da Resolução n. 117, de 20 de novembro de 1997, do Senado, que se pretendiam fossem inseridos à Resolução n. 69/1995, também da mesma Câmara Alta, que disciplinava, à época, as operações de crédito interno e externo realizadas

20 José Afonso da Silva. Comentário contextual à Constituição. 9. ed. atual. São Paulo: Malheiros, 2014, p. 419. 
pelos entes subnacionais, bem como a concessão de garantias, seus limites e condições de autorização.

No âmbito da MC-Adin, discutia-se se o Senado havia extrapolado sua competência constitucional ao estabelecer obrigações que restringiam a autonomia dos entes da Federação. O cerne do debate se restringia a dois incisos do artigo 13, da Resolução 69/95, acrescentados pela Resolução 117/97, assim descritos:

Art. 13. Os Estados, o Distrito Federal, os Municípios e suas respectivas autarquias encaminharão ao Senado Federal, por intermédio do Banco Central do Brasil, os pedidos de autorização para a realização das operações de crédito de que trata esta Resolução, instruídos com:

(...)

$\mathrm{X}$ - certidão expedida pelo respectivo Tribunal de Contas atestando o emprego de, no mínimo, 50\% (cinquenta por cento) da receita havida pelo Estado, Distrito Federal ou pelo Município com a privatização de entidades da administração indireta, na amortização ou liquidação do principal e acessórios das seguintes obrigações financeiras:

a) dívida pública mobiliária;

b) dívida pública fundada, nesta incluídos os empréstimos contratados por órgãos da administração direta, indireta e entidades autárquicas com instituições financeiras nacionais e estrangeiras, com organismos internacionais, ou ainda, com a União;

c) precatórios judiciários;

d) na constituição de fundos para o pagamento de benefícios previdenciários a servidores públicos, que vierem a ser criados no âmbito dos Estados, do Distrito Federal e dos Municípios.

XI - quadro de usos e fontes de recursos provenientes da privatização de entidades da administração indireta, arrecadados desde $1^{\circ}$ de janeiro de $1995(\ldots.) .^{21}$

Percebe-se que na resolução questionada havia incisos que se imiscuíam na esfera de competência e atuação dos entes subnacionais, condicionando a autorização para a realização de operações de crédito à prova de que os entes subnacio-

21 Atualmente, esses procedimentos para a realização de operações de crédito encontram-se disciplinados no Capítulo IV da Resolução 43/2001. No artigo 21 constam os documentos e requisitos necessários para a instrução do pleito. No artigo 22 da mesma resolução há a disposição acerca da documentação necessária para os casos de operação de crédito por antecipação de receita orçamentária. Já no artigo 23 estão relacionados os documentos pertinentes às operações de crédito (internas ou externas) que envolvam aval ou garantia da União. 
nais utilizavam parte de seus recursos (não os oriundos da própria operação de crédito) para determinada política de privatização.

Em que pesem as boas intenções presentes na resolução, na qual se pretendia estabelecer um programa de redução do endividamento público, o fato é que não caberia ao Senado ditar qual política deveria ser adotada pelo ente subnacional para, a partir daí, dar seguimento ao seu pleito, qual seja, a realização da operação de crédito.

Atento a esse fato, o relator, Ministro Octavio Gallotti, assim se pronunciou quando do julgamento da MC-Adin 1728:

É ilustrativa, para avaliar-se a assertiva de excesso da competência conferida pelo art. 52, VII, da Constituição, ao Senado Federal, a comparação entre o conteúdo dos nove anteriores incisos da Resolução n. 69-95, de um lado, e, de outro, dos dois outros, que lhe foram acrescentados pela Resolução n. 117-97, ora impugnados.

Instituem, os primeiros (I a IX), não mais do que regras formais de procedimento e instrução, como as relativas à comprovação da observância de obrigações legais, ao passo que, dos últimos (X e XI), objeto da presente ação, ressalta a imposição material do cumprimento de obrigação substantiva, derivada, não da obediência a requisito legal preexistente, mas da assunção de determinada opção política ou administrativa: escolha de determinados fins para a aplicação dos recursos provenientes de outras fontes, cuja gestão naturalmente se insere na competência legislativa e de autogoverno dos Estados e dos Municípios (artigos $1^{\circ}, 25,30,34,35$ e 39, $\mathbb{S} 1^{\circ}$, todos da Constituição). Não se cuida, assim, da edição de prescrições limitativas da destinação do produto da própria operação de crédito a ser autorizada, porém da designação de receita oriunda de causa perfeitamente diversa, qual seja o produto da privatização de entidades da administração indireta.

(...)

O que ora se contesta, e com indiscutível plausibilidade, é a legitimidade da interferência consistente na seleção, pelo Órgão federal, de determinadas ações políticas ou administrativas da alçada dos Estados, do Distrito Federal e dos Municípios, como condição prévia e terminativa do acesso dessas Unidades, ao próprio exame das operações de crédito que pretendam submeter ao elevado crivo do Senado Federal.

No mesmo sentido, o Ministro Nelson Jobim assim destacou:

Se a Constituição Federal condiciona, em seu art. 52, inciso VII, que o Senado deve:

'VII - dispor sobre limites globais e condições para as operações de crédito externo e interno da União, dos Estados, do Distrito Federal e dos Municí- 
pios, de suas autarquias e demais entidades controladas pelo poder público federal;'

O Senado não pode estabelecer, como condição para os financiamentos externos, eventualmente necessários dos Estados, que se destinem valores relativos às privatizações para amortização de dívida pública mobiliária etc.

Em reforço a esse argumento, pode-se citar a lição de Cesar A. Guimarães Pereira $^{22}$, que bem demonstra o âmbito de atuação do Senado em confronto com o artigo 52 da Constituição Federal:

Por outro lado, com exceção do inciso V, as competências do Senado Federal são eminentemente normativas. Apenas em relação às operações externas é que o Senado detém competência para praticar atos concretos de autorização (que é, por definição, prévia), sempre à luz de interesses de transcendência nacional. Nos outros campos, não se concebe que o Senado pretenda formular juízo de oportunidade ou conveniência sobre as operações de crédito de interesse dos Estados, Distrito Federal e Municípios.

Depreende-se, assim, que o fato de o Senado possuir poderes para estabelecer restrições e condições para as operações de crédito dos entes federados não lhe confere, porém, domínio para invadir, como bem ressalta Regis Fernandes de Oliveira, "a intimidade - autonomia prevista na forma federativa - de Estados, Distrito Federal e Municípios"23, obrigando-os a adotar políticas e procedimentos não diretamente afetos aos recursos objeto das operações de crédito.

Se é bem verdade que o Senado não pode interferir nas políticas adotadas por cada ente federado, não menos verdade é que o mandamento constitucional (artigo 52, inciso VII) lhe autoriza estabelecer limites e condições para as operações de crédito.

É também em razão dessa autorização dada pela Constituição Federal que a Resolução 43/2001 veda a prática, por parte dos entes federados, de algumas operações, como descritas em seu artigo $5^{\circ}$ :

Art. $5^{\circ}$ É vedado aos Estados, ao Distrito Federal e aos Municípios:

I - recebimento antecipado de valores de empresa em que o Poder Público detenha, direta ou indiretamente, a maioria do capital social com direito a voto, salvo lucros e dividendos, na forma da legislação;

22 O Endividamento Público na Lei de Responsabilidade Fiscal. In: ROCHA, Valdir de Oliveira (coord.). Aspectos relevantes da lei de responsabilidade fiscal. São Paulo: Dialética, 2001, p. 55.

${ }^{23}$ Regis Fernandes de Oliveira, Curso de direito financeiro. 7. ed. rev., atual. e ampl. São Paulo: Editora Revista dos Tribunais, 2015, p. 1043. 
II - assunção direta de compromisso, confissão de dívida ou operação assemelhada, com fornecedor de bens, mercadorias ou serviços, mediante emissão, aceite ou aval de títulos de crédito, não se aplicando esta vedação a empresas estatais dependentes;

III - assunção de obrigação, sem autorização orçamentária, com fornecedores para pagamento a posteriori de bens e serviços;

IV - realizar operação de crédito que represente violação dos acordos de refinanciamento firmados com a União;

$\mathrm{V}$ - conceder qualquer subsídio ou isenção, redução da base de cálculo, concessão de crédito presumido, incentivos, anistias, remissão, reduções de alíquotas e quaisquer outros benefícios tributários, fiscais ou financeiros, não autorizados na forma de lei específica, estadual ou municipal, que regule exclusivamente as matérias retro enumeradas ou o correspondente tributo ou contribuição.

VI - em relação aos créditos decorrentes do direito dos Estados, dos Municípios e do Distrito Federal, de participação governamental obrigatória, nas modalidades de royalties, participações especiais e compensações financeiras, no resultado da exploração de petróleo e gás natural, de recursos hídricos para fins de energia elétrica e de outros recursos minerais no respectivo território, plataforma continental ou zona econômica exclusiva:

a) ceder direitos relativos a período posterior ao do mandato do chefe do Poder Executivo, exceto para capitalização de Fundos de Previdência ou para amortização extraordinária de dívidas com a União;

b) dar em garantia ou captar recursos a título de adiantamento ou antecipação, cujas obrigações contratuais respectivas ultrapassem o mandato do chefe do Poder Executivo.

VII - em relação aos créditos inscritos em dívida ativa:

a) ceder o fluxo de recebimentos relativos aos direitos creditórios da dívida ativa de forma não definitiva ou com cláusula revogatória;

b) ceder o fluxo de recebimentos relativos aos direitos creditórios da dívida ativa com assunção, pelo Estado, pelo Distrito Federal ou pelo Município, perante o cessionário, de responsabilidade pelo efetivo pagamento a cargo do contribuinte ou de qualquer outra espécie de compromisso financeiro que possa, nos termos da Lei Complementar n. 101, de 4 de maio de 2000, caracterizar operação de crédito. (...)

Essas vedações, conquanto restrinjam a liberdade dos entes subnacionais para a obtenção de empréstimos e para a realização de operações de crédito, têm como premissa o estabelecimento de uma organização e padronização de procedimentos, com vistas a evitar operações que, se praticadas pelos entes subnacionais, acarretariam um descompasso das finanças da própria Federação. A responsabilidade fiscal é, portanto, o principal objetivo dos impedimentos previstos na Resolução 43/2001. 
O ferimento à autonomia do ente subnacional não ocorre porque é justamente a Constituição Federal que restringe sua liberdade no tocante à realização de operações de crédito, atrelando-as aos parâmetros a serem traçados pelo Senado. Aliás, nada mais salutar conferir essa atribuição à Câmara Alta, pois é o locus ideal para dirimir eventuais conflitos presentes na Federação, dada a representação paritária que Estados e Distrito Federal possuem no referido órgão.

Até mesmo a limitação da aplicação dos recursos objeto das operações de crédito não constituiria violação à autonomia dos entes federados. Esse, aliás, foi o entendimento do voto do Ministro Octavio Gallotti na já citada MC-Adin 1728, quando, se referindo à resolução impugnada, declarou que "até quando se ativesse ao emprego dos recursos levantados com a realização do crédito sujeito à sua aprovação, seria lícito, sem dúvida, ao Senado, dispor sobre a finalidade do dispêndio estadual ou municipal". No mesmo processo e no mesmo ângulo de compreensão foi a manifestação do Ministro Marco Aurélio, ao declarar, também em relação à resolução impugnada, que "admitiria a condição imposta para o emprego dos valores relativos a empréstimos a serem alcançados e autorizados pelo Senado Federal".

A existência de restrições ao endividamento constitui uma proteção à Federação ${ }^{24}$. Como bem observa Sérgio Assoni Filho ${ }^{25}$,

Uma vez limitado o endividamento público, mediante uma gestão fiscal que sinaliza no sentido da responsabilidade e moralidade no trato da coisa pública, e que penaliza e obriga a recondução da dívida a limites, maior será a credibilidade do País com os prestamistas nacionais e estrangeiros, ficando mais fácil encontrar financiadores para investimentos considerados relevantes pelos agentes públicos. Investimentos estes inviabilizados pela ausência de recursos públicos, caso não haja a possibilidade de recorrer ao uso do crédito público.

Depreende-se, assim, que as resoluções do Senado, embora possuam disposições que restrinjam o poder de os entes subnacionais se endividarem, não ferem suas respectivas autonomias, seja porque expressamente autorizadas pela Constituição, seja pelo fato de terem como objetivo um fim maior, qual seja, a sobrevivência da própria Federação.

${ }^{24}$ Embora, como bem afirma José Mauricio Conti (Levando o direito financeiro a sério: a luta continua. $2^{a}$ ed., São Paulo: Blucher, 2018, p. 387), não seja "fácil conciliar a autonomia dos entes subnacionais com a plena gestão da respectiva dívida, ao mesmo tempo em que é preciso manter um rígido controle do endividamento e evitar descontrole das contas".

25 Crédito público e responsabilidade fiscal. Porto Alegre: Núria Fabris Editora, 2007, p. 116-117. 


\subsection{0 trâmite de autorização do Senado para a realização de determinadas operações de crédito e novamente a questão da autonomia dos entes subnacionais}

Se é possível afirmar que do ponto de vista jurídico, legal e constitucional as limitações impostas nas resoluções do Senado não implicam ferimento à autonomia dos entes subnacionais, o mesmo talvez não se possa falar sob a ótica procedimental para viabilizar as operações de crédito por parte desses entes.

O artigo 28 da Resolução 43/2001 prevê a necessidade de autorização específica do Senado para as operações de crédito externo, para as decorrentes de convênios para aquisição de bens e serviços no exterior, para a emissão de títulos da dívida pública, bem como para emissão de debêntures ou assunção de obrigações por entidades controladas pelos Estados, pelo Distrito Federal e pelos Municípios que não exerçam atividade produtiva ou não possuam fonte própria de receitas. As demais operações de crédito, que não as listadas acima, passam apenas pelo crivo do Ministério da Fazenda ${ }^{26}$. Ao restringir determinadas operações de crédito à aprovação particularizada do Senado,

os senadores passaram a estudar mais detalhadamente as operações com maior potencial de geração de riscos para a Federação. O histórico brasileiro de crises de câmbio implica a necessidade de mais cautela ao analisar a dívida externa. Um endividamento excessivo em letras, por outro lado, pode gerar uma crise no mercado financeiro, algo que já ocorreu em meados da década de 1980. Finalmente, a emissão de debêntures, hoje rara, foi caracterizada no passado por corrupção ou pela superação dos limites de endividamento, justificando sua inclusão entre as operações que exigem análise por parte do Senado. ${ }^{27}$

Para que haja essa autorização específica do Senado, o pleito dos Estados, do Distrito Federal e dos Municípios deve ser submetido, em primeiro lugar, ao Mi-

26 Confira-se o que estabelece o artigo 31 da Resolução 43/2001: "Art. 31. As operações de crédito não sujeitas a autorização específica do Senado Federal serão objeto do seguinte procedimento pelo Ministério da Fazenda: I - os pleitos que não atenderem aos requisitos mínimos definidos no art. 32 serão indeferidos de imediato; II - os pleitos que atenderem aos requisitos mínimos, definidos no art. 32, serão autorizados no prazo máximo de 10 (dez) dias úteis.”

27 Paulo Roberto Arvate; Ciro Biderman; Marcos Mendes. Aprovação de empréstimos a governos subnacionais no Brasil: há espaço para comportamento político oportunista? Dados, Rio de Janeiro, v. 51, n. 4, p. 990-991, 2008. Disponível em: <http://www.scielo.br/scielo.php?script=sci arttext\&pid=S0011-52582008000400006\&lng=en\&nrm=iso $>$. Acessado em: 14 de outubro de 2018. 
nistério da Fazenda, que, por intermédio da Secretaria do Tesouro Nacional (STN), analisará se o pedido atende aos requisitos mínimos exigidos pela Resolução $43 / 2001^{28}$.

Se não cumpridos esses requisitos, o Ministério da Fazenda devolve o pleito, não o submetendo ao Senado, o qual será apenas comunicado do fato ${ }^{29}$.

${ }^{28}$ De fato, assim preveem os artigos 29 e 32 da Resolução 43/2001: “Art. 29. Os pleitos referentes a operações de crédito sujeitas a autorização específica do Senado Federal serão encaminhados pelo Ministério da Fazenda ao Senado Federal quando atenderem aos requisitos mínimos definidos no art. 32, acompanhados de parecer técnico que contenha, obrigatoriamente, os seguintes pontos: I - demonstrativo do cumprimento dos requisitos mínimos definidos no art. 32; II - informações que permitam avaliar o custo financeiro da operação de crédito; e III - demonstrativo do perfil de endividamento da entidade pública solicitante, antes e depois da realização da operação. $\mathbb{1} 1^{\circ} \mathrm{O}$ parecer a que se refere o caput incluirá, obrigatoriamente, manifestação favorável ou contrária em relação ao cumprimento dos limites e condições de que trata o art. 32 da Lei Complementar n. 101, de 2000, e as Resoluções do Senado Federal. $\mathbb{S} 2^{\circ}$ Nos pleitos relativos a emissão de títulos da dívida pública, o parecer a que se refere o caput conterá, também: I - especificação do valor dos títulos a serem emitidos e do valor do estoque de títulos do mesmo emissor já existentes, com indicação das datas de referência de tais valores; II - análise do impacto da operação de crédito no mercado mobiliário e do desempenho dos títulos já emitidos nesse mercado; e III - em se tratando de refinanciamento de títulos vincendos, histórico da evolução dos títulos desde sua emissão, registrando-se sua valorização ao longo do tempo. $\mathbb{S} 3^{\circ}$ Os pareceres técnicos e jurídicos apresentados pelo ente nos termos do inciso I do art. 21 serão encaminhados ao Senado Federal anexados ao parecer técnico definido no caput. (...) Art. 32. Considera-se requisito mínimo, para os fins desta Resolução, o cumprimento, quando se aplicar, do disposto nos arts. 5, 6, 7, 8, 9, 10, 11, 12, 13, 14, 15, 18, 21, 22 e $23 . \$ 1^{\circ}$ Os requisitos de que tratam o art. 16 e o inciso VIII do art. 21 serão comprovados à instituição financeira ou ao contratante, conforme o caso, por ocasião da assinatura do contrato. $\mathbb{\$} 2^{\circ}$ Os Estados, o Distrito Federal e os Municípios são obrigados a promover, junto ao Cadastro Nacional da Pessoa Jurídica (CNPJ), até o dia 30 de junho de 2013, a vinculação de todos os CNPJs de suas unidades administrativas ou órgãos que não possuem personalidade jurídica própria ao CNPJ principal da entidade tomadora da operação de crédito. $\mathbb{S} 3^{\circ}$ Durante a vigência do prazo estabelecido no $\mathbb{S} 2^{\circ}$, a comprovação a que se referem o $\mathbb{S} 1^{\circ}$ deste artigo, o parágrafo único do art. 16 e o $\$ 5^{\circ}$ do art. 21 será realizada pelo CNPJ principal da entidade tomadora da operação de crédito."

29 O artigo 30 da Resolução 43/2001 dispõe: “Art. 30. Quando não atenderem aos requisitos mínimos definidos no art. 32, os pleitos referentes a operações de crédito sujeitas a autorização específica do Senado Federal não serão encaminhados pelo Ministério da Fazenda ao Senado Federal. Parágrafo único. O Ministério da Fazenda devolverá os pleitos a que se refere o caput, ao Estado, ao Distrito Federal ou ao Município de origem, comunicando o fato ao Senado Federal.” 
Na hipótese de preenchimento dos requisitos, o pedido é, então, encaminhado à Comissão de Assuntos Econômicos (CAE) do Senado. Nessa comissão há a designação de um relator para a proposta ${ }^{30}$, cuja atribuição é emitir parecer e submeter seu relatório ao plenário da CAE e, após, à sessão plenária da Câmara Alta.

Ponto relevante é o de, justamente, perquirir se há a possibilidade de interferência política durante tal procedimento, a qual pode, ainda que de forma indireta, interferir na autonomia dos entes subnacionais que procuram aprovação para seus pleitos de endividamento.

Um estudo mais profundo sobre a questão foi realizado por Paulo Roberto Arvate, Ciro Biderman e Marcos Mendes ${ }^{31}$, no qual analisaram as solicitações apresentadas ao Senado entre 1989 e 2001 . Nesse exame, constataram que quase todos os pleitos de endividamento foram aprovados pelos senadores, talvez como uma forma de reciprocidade, "segundo a qual um senador não votaria contra empréstimos ao Estado de outro para que o representante desse Estado não votasse, no futuro, contra o Estado do primeiro" ${ }^{32}$.

Tal fato, por si só, já demonstraria certa parcialidade do Senado no exame dos pedidos, o que contraria a lógica e o princípio que fundamentam a necessidade de participação da Câmara Alta em tais deliberações. Afinal, o consentimento expresso do Senado deveria representar uma chancela confiável de proteção à Federação, sem influência de interesses outros que não a defesa das finanças da nação.

É por essa razão que se mostra pertinente que toda a documentação que compõe o pedido de endividamento do ente subnacional não se mostre apenas completo e bem fundamentado - em obediência aos termos da Resolução 43/2001 -, mas também didático. Além disso, deve-se exigir que as manifestações do

30 Assim estabelece o artigo 35 da Resolução 43/2001: “Art. 35. A indicação dos relatores dos pedidos de autorização para realização de operações de crédito de que trata esta Resolução será feita mediante a estrita observância da ordem de entrada do pedido na Comissão de Assuntos Econômicos e da relação de membros titulares da mesma Comissão, nos termos do art. 126 do Regimento Interno do Senado Federal. Parágrafo único. Senador já indicado como relator de pedido de que trata o caput não será designado novamente antes que todos os membros titulares da referida Comissão tenham sido designados relatores de pedidos da mesma espécie”.

31 Aprovação de empréstimos a governos subnacionais no Brasil: há espaço para comportamento político oportunista? Dados, Rio de Janeiro, v. 51, n. 4, p. 983-1014, 2008. Disponível em: <http://www.scielo.br/scielo.php?script=sci_arttext\&pid=S0011-

52582008000400006\&lng=en\&nrm=iso >. Acessado em: 14 de outubro de 2018.

32 Op. cit., p. 991. 
Senado, principalmente as que deferem operações de crédito externo, sejam igualmente didáticas e bem fundamentadas. Essas duas medidas darão maior transparência aos procedimentos e permitirão não só que os órgãos de controle atuem precisamente no controle das operações de crédito, mas também possibilitarão que o controle social seja exercido de uma forma mais eficaz.

Não obstante a quase unanimidade de aprovações dos pleitos de endividamento, a grande variação encontrada no estudo mencionado residiu, justamente, no prazo que o Senado demorava - a partir do momento em que a solicitação lhe era encaminhada - para concluir tal aprovação. A existência de variações no prazo indicava eventuais interferências de fatores políticos e, assim, certa fragilidade na necessária neutralidade que devem se revestir os procedimentos de controle do endividamento público dos entes subnacionais ${ }^{33}$. Os autores entendem como

'fatores políticos' aqueles que levam a negociações não associadas com o objetivo principal do mecanismo de controle sobre endividamento (preservar a liquidez e a solvência das contas públicas), em que a prerrogativa senatorial de 'criar dificuldades' para aprovação de uma solicitação é usada por senadores para 'vender facilidades'. Não falamos aqui de corrupção, mas do uso do mecanismo de controle de dívidas para obter ganhos políticos, como uma manipulação oportunista à luz do ciclo eleitoral, conforme mostra a literatura. Por exemplo, um aumento dos recursos para seu próprio Estado ou uma posição vantajosa em disputas eleitorais vindouras. ${ }^{34}$

Outra espécie de interferência política pode ser ocasionada pela atuação do próprio Executivo federal:

Embora o prazo de aprovação seja definido pelo Legislativo, o presidente da República costuma ter influência sobre o Congresso. Assim, uma solicitação apresentada por um governador aliado do presidente, por exemplo, poderia adquirir peso político e ser aprovada mais rapidamente desde que o presidente contasse com maioria sólida e fiel no Senado. Entretanto, se o presidente não contar com tal maioria no plenário ou na CAE, seus aliados podem se deparar com prazos de aprovação mais longos. O senador usaria esse poder (temporário) para obter outros benefícios, como financiamento federal para projetos de interesse de sua própria base eleitoral. Nesse caso, o resultado seria um maior atraso da análise de solicitações de governadores ligados ao presidente. Quase metade das solicitações apresentadas ao Senado $(47 \%)$ apresenta alguma ligação entre o governador e o presidente. ${ }^{35}$

\footnotetext{
33 Op. cit., p. 992.

34 Op. cit., p. 992.

35 Op. cit., p. 994.
} 
A relação existente entre o governador que solicita o endividamento e o relator responsável no âmbito da CAE também é um fator que pode adiantar ou atrasar a análise do pleito, dependendo do alinhamento político que tiverem (coalizão eleitoral) $)^{36}$.

Tais fatos demonstram a possível interferência de fatores políticos e eleitorais no tempo de atendimento às solicitações de endividamento dos entes subnacionais, colocando em risco a imparcialidade do Senado para deliberações acerca desse tema.

Uma forma de evitar ingerências dessa espécie seria a designação de prazos determinados e mais rígidos nos procedimentos de aprovação do Senado, bem como uma maior transparência do trâmite dessas deliberações no âmbito da Câmara Alta, permitindo um controle apurado por parte dos entes subnacionais, bem como, principalmente, pela sociedade.

\subsection{O papel do Ministério da Fazenda nas operações de crédito dos entes subnacionais e a questão da separação dos Poderes e da autonomia dos entes federados}

O Ministério da Fazenda, com o advento da Lei de Responsabilidade Fiscal, passou a ter relevante papel no tocante às operações de crédito dos entes subnacionais. No artigo 32 da mencionada lei está demonstrada, claramente, sua atribuição para constatar a observância aos "limites e condições relativos à realização de operações de crédito de cada ente da Federação, inclusive das empresas por eles controladas, direta ou indiretamente".

Cabe ao Ministério da Fazenda, ainda, realizar o registro, de forma centralizada, atualizada e eletrônica, das dívidas públicas interna e externa, permitindo que os seguintes dados sejam disponibilizados à sociedade: a) encargos e condições de contratação das dívidas públicas; b) saldos atualizados e limites referentes às dívidas consolidada e mobiliária, operações de crédito e concessões de garantias $^{37}$. É por intermédio dessas informações que será possível o exercício do controle social sobre o endividamento do setor público. Como bem ressalta José Mauricio Conti, o objetivo é "assegurar ao cidadão o direito de receber dos órgãos públicos informações de seu interesse particular ou de interesse geral”, em obediência ao artigo $5^{\circ}$, inciso XXXIII, da Constituição Federal ${ }^{38}$.

36 Op. cit., p. 995, 1006.

37 Artigo 32, $\mathbb{S} 4^{\circ}$, da Lei de Responsabilidade Fiscal.

38 Arts. 32 a 39. In: MARTINS, Ives Gandra da Silva e NASCIMENTO, Carlos Valder. Comentários à Lei de Responsabilidade Fiscal. São Paulo: Saraiva, 2001, p. 226. 
Essas atribuições conferidas ao Ministério da Fazenda deixam evidente sua função de monitorar o endividamento dos entes subnacionais.

A questão, então, é perquirir se esse encargo exercido pelo órgão acaba por ferir o princípio da Separação de Poderes ou mesmo a autonomia dos Estados, do Distrito Federal e dos Municípios.

Conforme leciona Regis Fernandes de Oliveira, "poder-se-ia questionar se é constitucional a submissão de Estados e Municípios ao atendimento de exigências perante o Ministério da Fazenda. Nada há de inconstitucional, uma vez que funcionará ele como mero órgão encarregado do processamento do pedido. Evidentemente que cabe a ele o exame do atendimento das exigências legais, podendo exigir os documentos legais" 39 .

Nesse sentido, o Ministério da Fazenda deverá verificar, objetivamente, o cumprimento aos incisos do $\mathbb{S} 1^{\circ}$, do artigo 32, da Lei de Responsabilidade Fiscal, não avançando em demais detalhes para deferir ou indeferir o pleito do ente subnacional.

Parece ser esse, também, o entendimento de Cesar A. Guimarães Pereira ${ }^{40}$ :

61. Essa interpretação resulta de uma acomodação do texto do art. 32 aos dispositivos constitucionais. Seria inválida a submissão das operações de crédito dos Estados, Distrito Federal e Municípios a uma autorização prévia de órgão federal. A competência da União é normativa e se relaciona com a edição de normas gerais (por lei complementar) ou certos limites e condições das operações (pelo Senado). Com exceção do disposto no art. 52, V, não detém competência decisória nesse campo.

Desse modo, o Ministério da Fazenda apenas pode operar como órgão centralizador de informações e verificador de requisitos formais das operações. (...)

Também no caso do art. 32, o Ministério da Fazenda apenas pode praticar atos estritamente vinculados, que tenham por objeto apenas a verificação dos requisitos. Uma vez atendidas as exigências da LRF (arts. 16, quando cabível, e 32), deve ser obrigatoriamente 'autorizada' a operação de crédito. Não cabe ao Ministério da Fazenda realizar nenhum juízo acerca da 'relação custo-benefício’ e do 'interesse econômico e social da operação’ (art. 32, caput). Esse exame competirá exclusivamente aos órgãos de controle.

39 Responsabilidade fiscal. 2. ed. rev. São Paulo: Revista dos Tribunais, 2002, p. 77.

40 O Endividamento Público na Lei de Responsabilidade Fiscal. In: ROCHA, Valdir de Oliveira (coord.). Aspectos relevantes da lei de responsabilidade fiscal. São Paulo: Dialética, 2001, p. $82-83$. 
A grande finalidade da tramitação prévia da operação de crédito perante o Ministério da Fazenda é o atendimento do $\mathbb{S} 4^{\circ}$ do art. 32, que determina a esse órgão a centralização e a disponibilização pública de informações sobre o endividamento público. Não pode ir além disso, sob pena de inconstitucionalidade por ofensa à autonomia dos Estados, Distrito Federal e Municípios.

O autor pondera que o processo administrativo do Ministério da Fazenda, no qual será analisado o preenchimento dos requisitos do artigo $32, \mathbb{S} 1^{\circ}$, da LRF, deverá ser dinâmico e sumário, sob pena de violar a autonomia dos entes subnacionais $^{41}$. De forma salutar, a Resolução 43/2001 estabelece um período máximo para análise do pleito pelo Ministério da Fazenda: trinta dias úteis, computados a partir do recebimento da documentação completa (art. 25, caput).

Importante mencionar que as condições mencionadas no $\mathbb{S} 1^{\circ}$, do artigo 32 , da LRF, não são exaustivas, mesmo porque o citado dispositivo faz referência à necessidade de atendimento a outras restrições da própria LRF (inciso VI), bem como à "observância dos limites e condições fixados pelo Senado Federal” (inciso III).

Até mesmo nessas hipóteses, não há como considerar que o Ministério da Fazenda deverá efetuar uma análise do mérito dos pedidos. Ao contrário: as disposições contidas no artigo 21 da Resolução 43/2001 do Senado, por exemplo, deixam claro que o papel do Ministério da Fazenda é o de colher todos os documentos necessários para os pleitos de realização de operações de crédito, não lhe concedendo nenhuma autorização para que examine a pertinência, a viabilidade ou a conveniência dos pedidos de endividamento formulados pelos entes subnacionais. Eis as exigências contidas no normativo mencionado:

Art. 21. Os Estados, o Distrito Federal e os Municípios encaminharão ao Ministério da Fazenda os pedidos de verificação de limites e condições para a realização das operações de crédito de que trata esta Resolução, com a proposta do financiamento ou empréstimo e instruídos com:

I - pedido do chefe do Poder Executivo, acompanhado de pareceres técnicos e jurídicos, demonstrando a relação custo-benefício, o interesse econômico e social da operação e o cumprimento dos limites e condições estabelecidos por esta Resolução;

II - autorização legislativa para a realização da operação;

III - declaração do Chefe do Poder Executivo, na forma exigida pelo Ministério da Fazenda, atestando a inclusão no orçamento vigente dos recursos

41 O Endividamento Público na Lei de Responsabilidade Fiscal. In: ROCHA, Valdir de Oliveira (coord.). Aspectos relevantes da lei de responsabilidade fiscal. São Paulo: Dialética, 2001, p. 83. 
provenientes da operação pleiteada, exceto no caso de operações por antecipação de receita orçamentária, ou, no caso em que o primeiro desembolso não se realize no ano da análise, declaração de inclusão no Projeto de Lei Orçamentária Anual (PLOA) do exercício subsequente, e desde que a autorização legislativa de que trata o inciso II tenha sido efetivada por meio de lei específica;

IV - certidão expedida pelo Tribunal de Contas competente atestando: a) em relação às contas do último exercício analisado, o cumprimento do disposto no $\mathbb{S} 2^{\circ}$ do art. 12 ; no art. 23 ; no art. 33; no art. 37; no art. 52; no $\mathbb{S} 2^{\circ}$ do art. 55; e no art. 70, todos da Lei Complementar n. 101, de 2000; b) em relação às contas dos exercícios ainda não analisados, e, quando pertinente, do exercício em curso, o cumprimento das exigências estabelecidas no $\mathbb{2} 2^{\circ}$ do art. 12 ; no art. 23 ; no art. 52 ; no $\mathbb{S} 2^{\circ}$ do art. 55 ; e no art. 70 , todos da Lei Complementar n. 101, de 2000, de acordo com as informações constantes nos relatórios resumidos da execução orçamentária e nos de gestão fiscal; c) a certidão deverá ser acompanhada de declaração do chefe do Poder Executivo de que as contas ainda não analisadas estão em conformidade com o disposto na alínea a;

V - declaração do chefe do Poder Executivo atestando o atendimento do inciso III do art. 5;

VI - comprovação da Secretaria do Tesouro Nacional quanto ao adimplemento com a União relativo aos financiamentos e refinanciamentos por ela concedidos, bem como às garantias a operações de crédito, que tenham sido, eventualmente, honradas;

VII - no caso específico de operações de Municípios com garantia de Estados, certidão emitida pela Secretaria responsável pela administração financeira do garantidor, que ateste a adimplência do tomador do crédito perante o Estado e as entidades por ele controladas, bem como a inexistência de débito decorrente de garantia a operação de crédito que tenha sido, eventualmente, honrada;

VIII - certidões que atestem a regularidade junto ao Programa de Integração Social (PIS), ao Programa de Formação do Patrimônio do Servidor Público (Pasep), ao Fundo de Investimento Social (Finsocial), à Contribuição Social para o Financiamento da Seguridade Social (Cofins), ao Instituto Nacional do Seguro Social (INSS) e ao Fundo de Garantia do Tempo de Serviço (FGTS) e, quando couber, na forma regulamentada pelo Ministério da Previdência e Assistência Social, o cumprimento da Lei n. 9.717, de 27 de novembro de 1998.

IX - cronogramas de dispêndio com as dívidas interna e externa e com a operação a ser realizada;

$\mathrm{X}$ - relação de todas as dívidas, com seus valores atualizados, inclusive daqueles vencidos e não pagos, assinada pelo chefe do Poder Executivo e pelo Secretário de Governo responsável pela administração financeira; 
XI - Relatórios Resumidos da Execução Orçamentária (RREO), assinados pelo Chefe do Poder Executivo e pelo Secretário de Governo responsável pela administração financeira, para fins de cálculo dos limites de que trata esta Resolução;

XII - comprovação do encaminhamento das contas ao Poder Executivo da União, para fins da consolidação de que trata o caput do art. 51 da Lei Complementar n. 101, de 2000;

XIII - comprovação das publicações a que se referem os arts. 52 e $55, \mathbb{} 2$, da Lei Complementar n. 101, de 2000;

XIV - Quadro demonstrativo da Receita e Despesa, segundo as Categorias Econômicas, integrante da lei de orçamento do exercício em curso, conforme inciso II do $\mathbb{S} 1^{\circ}$ do art. $2^{\circ}$ da Lei n. 4.320, de 17 de março de 1964, para fins de apuração do limite de que trata o art. $6^{\circ}$;

$\mathrm{XV}$ - cronograma estimativo de liberações das operações de crédito contratadas e a contratar;

XVI - cronograma estimativo de desembolso e reembolso da operação a ser contratada. (...)

Como se depreende dos dispositivos acima transcritos, não há que se falar em análise do Ministério da Fazenda acerca do cabimento ou não dos pleitos dos entes subnacionais.

Mais um exemplo diz respeito ao $\mathbb{S} 1^{\circ}$, do artigo 25, da Resolução 43/2001, do Senado, o qual prevê que, "caso o Ministério da Fazenda constate que a documentação recebida não é suficiente para sua análise, solicitará a complementação dos documentos e informações, fluindo igual prazo a partir do cumprimento das exigências”. Somente no caso de não envio no prazo estabelecido é que poderá o referido Ministério indeferir o pleito (art. 25, $\mathbb{S} 2^{\circ}$, da Resolução 43/2001); mesmo assim, em razão do não atendimento dos requisitos procedimentais por parte do ente subnacional, e não em razão do mérito do pedido.

Tanto nas operações de crédito sujeitas à autorização específica do Senado (artigo 29 da Resolução 43/2001), quanto naquelas em que não se exige tal aprovação (artigo 31), o papel primordial do Ministério da Fazenda é o de verificar se os pedidos atendem aos requisitos mínimos exigidos na própria resolução, ou seja, se as condições e restriçõos contidas na norma foram ou não observadas pelos entes subnacionais quando do envio do pleito de endividamento, não havendo qualquer deliberação do referido Ministério sobre o cabimento do pleito. No caso específico das operações de crédito que demandam autorização do Senado, nem mesmo a exigência adicional de parecer por parte do Ministério da Fazenda demonstra qualquer violação à autonomia dos entes federados ou ao princípio da Separação dos Poderes, pois tal opinião é apenas técnica, não se revestindo de 
caráter deliberativo ou vinculante, mantendo-se em mãos da Câmara Alta o poder de deferir ou não o pedido ${ }^{42}$.

Até nas hipóteses em que há a constatação de irregularidade na instrução do processo de verificação de limites e condições de endividamento, não cabe ao Ministério da Fazenda aplicar qualquer penalidade, devendo sua atuação restringir-se à devolução do pleito à origem, comunicando o Senado, o Poder Legislativo local e o Tribunal de Contas a que estiver jurisdicionado o pleiteante (art. 24, caput e $\int \mathbb{S} 1^{\circ}$ e $2^{\circ}$, da Resolução 43/2001).

${ }^{42}$ Para uma melhor compreensão da estrutura do procedimento envolvendo o Ministério da Fazenda, com a necessária constatação de seu papel não deliberativo, atenta-se ao que dispõem os artigos 29, 30, 31 e 32 da Resolução 43/2001: “Art. 29. Os pleitos referentes a operações de crédito sujeitas a autorização específica do Senado Federal serão encaminhados pelo Ministério da Fazenda ao Senado Federal quando atenderem aos requisitos mínimos definidos no art. 32, acompanhados de parecer técnico que contenha, obrigatoriamente, os seguintes pontos: I - demonstrativo do cumprimento dos requisitos mínimos definidos no art. 32; II - informações que permitam avaliar o custo financeiro da operação de crédito; e III - demonstrativo do perfil de endividamento da entidade pública solicitante, antes e depois da realização da operação. $\mathbb{S} 1^{\circ}$ O parecer a que se refere o caput incluirá, obrigatoriamente, manifestação favorável ou contrária em relação ao cumprimento dos limites e condições de que trata o art. 32 da Lei Complementar n. 101, de 2000, e as Resoluções do Senado Federal. $\$ 2^{\circ}$ Nos pleitos relativos a emissão de títulos da dívida pública, o parecer a que se refere o caput conterá, também: I - especificação do valor dos títulos a serem emitidos e do valor do estoque de títulos do mesmo emissor já existentes, com indicação das datas de referência de tais valores; II - análise do impacto da operação de crédito no mercado mobiliário e do desempenho dos títulos já emitidos nesse mercado; e III - em se tratando de refinanciamento de títulos vincendos, histórico da evolução dos títulos desde sua emissão, registrando-se sua valorização ao longo do tempo. $\mathbb{S} 3^{\circ}$ Os pareceres técnicos e jurídicos apresentados pelo ente nos termos do inciso I do art. 21 serão encaminhados ao Senado Federal anexados ao parecer técnico definido no caput. Art. 30. Quando não atenderem aos requisitos mínimos definidos no art. 32, os pleitos referentes a operações de crédito sujeitas a autorização específica do Senado Federal não serão encaminhados pelo Ministério da Fazenda ao Senado Federal. Parágrafo único. O Ministério da Fazenda devolverá os pleitos a que se refere o caput, ao Estado, ao Distrito Federal ou ao Município de origem, comunicando o fato ao Senado Federal. Art. 31. As operações de crédito não sujeitas a autorização específica do Senado Federal serão objeto do seguinte procedimento pelo Ministério da Fazenda: I - os pleitos que não atenderem aos requisitos mínimos definidos no art. 32 serão indeferidos de imediato; II - os pleitos que atenderem aos requisitos mínimos, definidos no art. 32, serão autorizados no prazo máximo de 10 (dez) dias úteis. Art. 32. Considera-se requisito mínimo, para os fins desta Resolução, o cumprimento, quando se aplicar, do disposto nos arts. 5, 6, 7, 8, 9, 10, 11, 12, 13, 14, 15, 18, 21, 22 e 23 [da Resolução 43/2001] (...)". 


\section{CONCLUSÃO}

Do ponto de vista histórico, a Federação brasileira já nasceu com alto grau de centralização, concentrando grandes poderes em mãos do governo central em detrimento dos entes subnacionais. Tal concentração pode trazer consequências funestas em determinados aspectos do federalismo fiscal.

O objeto do presente estudo, porém, não foi o de avaliar o grau de centralização da Federação brasileira, mas, partindo de uma de suas perspectivas, a fiscal, examinar qual o nível de autoridade que os entes subnacionais possuem para definir os rumos de seu próprio endividamento, bem como o poder que o governo central possui para influenciar nessa deliberação.

De uma forma geral, a existência de regras mais restritas para o endividamento dos entes subnacionais, previstas nas resoluções do Senado, acaba por reforçar a ideia de um grau maior de poder conferido ao governo central. Nem por isso, contudo, há que se falar em risco à autonomia dos Estados, Distrito Federal e Municípios.

De fato, o Senado possui poderes para definir parâmetros para o endividamento dos entes subnacionais, poderes esses expressamente conferidos pela Constituição brasileira e que acabam se concretizando pelas disposições da Lei de Responsabilidade Fiscal e das Resoluções 40 e 43 do próprio Senado.

A existência das resoluções não representa ferimento à autonomia dos entes subnacionais, muito embora nelas estejam inscritas restrições ao endividamento por parte desses entes. O estabelecimento de tais limites está autorizado pela Constituição Federal, não significando, porém, que a Câmara Alta possua liberdade para se imiscuir em detalhes da autonomia do ente federado. Ao contrário, o papel conferido ao Senado é o de definir balizas para permitir que o endividamento de cada ente federado não venha a colocar em risco a saúde financeira de toda a Federação.

O que pode levar ao ataque, ainda que indireto, à autonomia dos entes subnacionais, é a parcialidade do Senado, seja no tempo que demanda ao conferir autorização para a realização de operações de crédito externas, seja quando tais autorizações não estejam embasadas em critérios objetivos e estritamente relacionados à integridade das finanças da Federação.

Nessas hipóteses, o antídoto para desestimular tais práticas é a exigência de maior transparência dos procedimentos, permitindo que o controle da sociedade e dos demais órgãos responsáveis pela fiscalização ocorra de uma forma mais eficiente e eficaz.

A atribuição do Ministério da Fazenda de verificar a observância dos limites e condições relacionados à realização de operações de crédito em nenhum mo- 
mento fere a autonomia dos entes subnacionais, tampouco exerce indevida ingerência do Poder Executivo sobre os demais poderes, mesmo porque o mencionado ministério não elabora qualquer juízo de valor sobre os pleitos de endividamento, cabendo-lhe apenas processá-los, obedecendo a critérios objetivos previstos na Lei de Responsabilidade Fiscal e nas resoluções do Senado.

De tudo o que foi exposto, depreende-se que, sob a perspectiva fiscal, embora haja um grau maior de concentração de poder em mãos do governo central no que se refere ao endividamento público, as restrições impostas aos entes subnacionais não representam ferimento às suas autonomias, mas limitações necessárias para evitar gastos que não obedeçam ao planejamento necessário e às boas práticas de finanças públicas, limitações essas existentes com vistas a viabilizar a perenidade da Federação.

\section{REFERÊNCIAS}

ARVATE, Paulo Roberto; BIDERMAN, Ciro; MENDES, Marcos. Aprovação de empréstimos a governos subnacionais no Brasil: há espaço para comportamento político oportunista? Dados, Rio de Janeiro, v. 51, n. 4, p. 983-1014, 2008. Disponível em: $<$ http://www.scielo.br/scielo.php?script=sci_arttext\&pid=S001152582008000400006\&lng=en\&nrm=iso>. Acessado em: 14 out. 2018.

ASSONI FILHO, Sérgio. Crédito público e responsabilidade fiscal. Porto Alegre: Núria Fabris Editora, 2007.

CARVALHO, José Augusto Moreira de. Do exercício financeiro. In: CONTI, José Mauricio. Orçamentos Públicos: A Lei 4.320/1964 comentada. São Paulo: Revista dos Tribunais, p. 131-148.

CONTI, José Mauricio. Arts. 32 a 39. In: MARTINS, Ives Gandra da Silva e NASCIMENTO, Carlos Valder. Comentários à Lei de Responsabilidade Fiscal. São Paulo: Saraiva, 2001. p. 217-246.

CONTI, José Mauricio. Levando o direito financeiro a sério: a luta continua. 2. ed. São Paulo: Blucher, 2018.

MIOTO, Antonio Celso Banheta. Para onde vai o federalismo? Notas sobre o que foi e o que poderá vir a ser o Estado Federal. Revista de Direito Administrativo, Rio de Janeiro, v. 268, p. 187-211, jan. 2015. ISSN 2238-5177. Disponível em: <http:// bibliotecadigital.fgv.br/ojs/index.php/rda/article/view/50739>. Acesso em: 20 jul. 2018.

OLIVEIRA, Regis Fernandes de. Curso de direito financeiro. 7. ed., rev., atual. e ampl. São Paulo: Editora Revista dos Tribunais, 2015.

OLIVEIRA, Regis Fernandes de. Responsabilidade fiscal. 2. ed., rev. São Paulo: Revista dos Tribunais, 2002.

PEREIRA, Cesar A. Guimarães. O Endividamento Público na Lei de Responsabilidade Fiscal. In: ROCHA, Valdir de Oliveira (coord.). Aspectos relevantes da lei de responsabilidade fiscal. São Paulo: Dialética, 2001. p. 43-104. 
RODDEN, Jonathan. Federalismo e descentralização em perspectiva comparada: sobre significados e medidas. Tradução de Miriam Adelman e Marta Arretche. In: Revista de Sociologia e Política, Curitiba, n. 24, p. 9-27, Jun. 2005. Disponível em: <http://www. scielo.br/scielo.php?pid=S0104-44782005000100003\&script=sci_arttext\&tIng=>. Acessado em: 1 ago. 2018.

SILVA, José Afonso da. Comentário contextual à Constituição. 9. ed. atual. São Paulo: Malheiros, 2014.

\section{Julgados:}

MC-Adin 1728-DF, Relator Min. Octavio Galotti, julgado em 11.12.97, por unanimidade (Plenário), publicado no DJ de 14.12.2001.

MC-Adin 216-PB, Relator Min. Célio Borja, julgado em 23.05.90, por maioria (Tribunal Pleno), publicado no DJ de 07.05.93. 
